\title{
T.T. Cloete en die omdigting van die Psalms ${ }^{1}$
}

Mariana Venter

Buro vir Wetenskaplike Tydskrifte

Potchefstroomse Universiteit vir CHO

POTCHEFSTROOM

Sedert 1989 is T.T. Cloete saam met ander digters werksaam aan die omdigting van die Psalms - 'n taak wat, soos hy self sê, 'n nuwe dimensie in sy lewe ingedra het, maar ook 'n taak wat buitengewone eise stel: eksegeties en hermeneuties moet die Skrifgegewe in die omdigting met omsigtigheid vertolk word, die struktuurpatrone van die grondtaal moet nie onnodig versteur word nie en die eindproduk moet musikologies en harmonies aanvaarbaar op die oor val. In hierdie opsig is die bestaande Geneefse melodie soms 'n verdere dwangmeester wat die verslengte en die strofebou bepaal. Waar ook die melodie in berekening gebring moet word, moet hierdie 'ruimte' sinvol 'ingevul' word met Skrifgetroue inhoud. En wat poëties, semanties en taalkundig 'normaal' is, is nie altyd singbaar nie - die omdigtings moet uiteindelik in aldagtaal gesing word. Woorde, betekenisnuanses, verse en lettergrepe moet dus letterlik en figuurlik geweeg en getel word.

Van Cloete as digter-vertolker word verwag dat alle elemente uiteindelik sal sáámklink en daarom moet hy voortdurend sáámdink en die insette van eksegete, hermeneute, musikoloë, vakkundiges en adviseurs verantwoordelik gebruik sonder om stilistiese verfyning of poëtikale kwaliteit in te boet. Ritme, rym, woordklank, betekenis, die aantal lettergrepe, die musikale 'rangskikking' van die woordklank en die logiese toonsetting van die teks moet met 'n kundige hand in harmoniese vennootskap saamgevoeg word.

In hierdie bydrae plaas ons slegs een van die voorstadiums van hierdie omdigtingsproses - Psalm 90 - 'n omdigting wat nog in proses is en nie finaal

Ons dank aan prof. D.H. Steenberg, redakteur van Literator vir die vergunning om hierdie bydrae oor te neem in In die Skriflig (oorspronklik gepubliseer in Literator, 16(3) Nov. 1995). Daar is besluit om hierdie bydrae in In die Skriflig oor te neem omdat dit nou aansluit by T.T. Cloete se artikel "Die nuwe omdigting van die Psaims in Afrikaans as kreatiewe werk" wat elders in dié nommer verskyn JHvW ns. Redaksie. 
goedgekeur is nie. Hierdie voorbeeld illustreer egter dat hierdie omdigtings inderdaad die produk is van baie nadink, oorskryf, die uitsif van die mees gepaste variant. Die kommentaar en variante wat Cloete tussen die reëls invoeg, lewer bewys van hierdie nougesette en deeglike arbeid.

Die voorstadium van Psalm 90 asook die verdere verwerking is egter alreeds die produk van wéér lees, krities besin en redigeer - tog is dit nog steeds 'n voorfinale teks. Die talle asteriske en gedeeltes tussen hakies dui byvoorbeeld aan dat Cloete op daardie spesifieke plekke een of ander besonderheidjie wou kontroleer.

Van Psalm 65 word slegs 'n fragment geplaas (die vyfde strofe). Wanneer die Cloete-teks van hierdie vyfde strofe van Psalm 65 krities gelees word naas die vyf verse uit die Bybelteks waarop dit gebaseer is, dan is dit duidelik dat 'n omdigting ook soms 'n suksesvolle verdigting tot gevolg het.

\section{Psalm 90 - 'n voorstadium ${ }^{2}$}

[bewerking T.T. Cloete] [eksegese Ridderbos, Lamparter, Weiser] [melodie bly behoue] [eerste indiening by $\mathrm{Sk} 2$ begin 1995]

1

$U$ was vir ons 'n toevlug altyd, Here, geslagte lank, ontelbaar aantal kere. [wtv gangbaar]

[deur ons/die geslagte ongetelde kere

Van ewig af is $U$, van lank tevore, toe was die berge nog nie eers gebore.

Toe was $U$ daar, by wie ons skuil kan gaan. $U$, God, van voor die wêreld se ontstaan.

of: wat daarvan as ons die beginverse omruil?:

$U$ was geslagte na geslagte, Here,

'n toevlug ongetelde aantal kere.

[vir ons 'n toevlug ongetelde kere.]

2 Cloete se eie kommentaar, notas en woordkeusemoontlikhede in die omdigtingsproses word tipografies met 'n kleiner lettertipe onderskei. 
of:

U was geslagte lank, sovele/ontelbaar kere, vir ons 'n toevlug en 'n skuiling [Ndl./Tot.], Here.

of [vir my nog die beste]:

$U$ was vir ons geslagte lank, o Here, ons/'n toevlug en ons/'n skuiling soveel/baie kere. [ 1 aand !!!!]

U sê: "word stof", dan sterfons in 'n oogknip.

Vir $U$ is duisend jaar 'n kleine tydstip, soos gister wat haas ongemerk verbygaan,

[die dag van gister wat net so/so snel/vlug verbygaan,] soos een beurt van ' $n$ nagtelike wagstaan

[oorspr.: 'n enkel nagtelike beurt van wagstaan.]

Soos gras staan ons nog soggens groen en hoog,

[twvd soos: Ons staan soos gras nog soggens groen en hoog,]

dan sny $U$ ons, en saans is ons verdroog.

3

Ons gaan vanweë [2 sill.] u gramskap, God, te gronde.

$U$ oog belig ons weggesteekte sonde.

Ons jare vlieg daarheen * soos 'n gedagte. [vgl. WAT/HAT]

Ons haal 'n kleine sewentig of tagtig,

en dié is vol van swaarky en van leed

en is tot niet ${ }^{* *}$ nog voor ons dit goed weet.

[oorspr. "verby"; Daleen: die ver moet ne op 'n lang noot lê nie - maar dit lê mos nie op 'n lang noot nie?]

4

Wie ken $u$ gramskap beter as $u$ dienaar?

Dit maak te meer die lewe vir hom dierbaar.

Laat, Here, ons dan tog ons dae aftel [OV],

ons lewensjare wat so vlug verbysnel; [herh.: vgl str. 2]

laat ons die tyd benut, Heer, leer ons dit, dat ons ' $n$ hart [OV] wat wys is mag besit. 
Hoe lank nog voor U, Here, ons te hulp kom.

Skenk ons u liefde in sy volle rykdom.

Gee ons nou soveel jare, Here, blydskap, soveel as wat verduur is van u gramskap.

[net soos die wat verduur is van u gramskap.]

[oorspr.: as dié wat ons verduur het van u gramskap.]

Maak ons dan tog ons lewe lank nou bly [;]

[Maak U ons nou ons lewe lank dan bly [;]]

en maak van $u$ verdrukking ons nou vry.

[laat gaan, Heer, ons verdrukking nou verby.]

6

$U$ wat $u$ werk met ons in wysheid inrig, gee daarin duidelik vir ons ' $n$ insig, skerp ons dit diep in, Heer, in ons gedagte en wys $u$ grootheid vir ons nageslagte. Dit wat ons kon bewerk het met ons hand, hou, Here, daardie werk van ons in stand.

[Hier het die melodie, wat behoue moet bly, dan daardie melodies sogenaamd "moeilike" elf lettergrepe ] 


\section{Psalm 90 - 'n voorfinale weergawe}

(Omdigting - T.T. Cloete)

1

$\mathrm{U}$ was vir ons ' $n$ toevlug altyd, Here, geslagte lank, ontelbaar aantal kere.

Van ewig af is $U$, van lank tevore, toe was die berge nog nie eers gebore.

Toe was $U$ daar, by wie ons skuil kan gaan. $\mathrm{U}$, God, van voor die wêreld se ontstaan.

\section{2}

U sê: "word stof", dan sterf ons in 'n oogknip.

Vir $U$ is duisend jaar ' $n$ kjeine tydstip, soos gister wat haas ongemerk verbygaan, soos een beurt van 'n nagtelike wagstaan.

Soos gras staan ons nog soggens groen en hoog, dan sny $U$ ons, en saans is ons verdroog.

3

Ons gaan vanweē u gramskap, God, te gronde. $\mathrm{U}$ oog belig ons weggesteekte sonde.

Ons jare vlieg daarheen/soos 'n gedagte.

Ons haal 'n kleine sewentig of tagtig, en die is vol van swarkry en van leed en is tot niet nog voor ons dit goed weet.
4

Wie ken u gramskap beter as u dienaar?

Dit maak te meer die lewe vir hom dierbaar.

Laat, Here, ons dan tog ons dae aftel, ons lewensjare wat so vlug verbysnel; laat ons die tyd benut, Heer, leer ons dit, dat ons 'n hart wat wys is mag besit.

\section{5}

Hoe lank nog voor U, Here, ons te hulp kom. Skenk ons u liefde in sy volle rykdom. Gee ons nou soveel jare, Here, blydskap, soveel as wat verduur is van u gramskap. Maak ons dan tog ons lewe lank nou bly; en maak van u verdrukking ons nou vry.

6

$U$ wat $u$ werk met ons in wysheid inrig, gee darin duidelik vir ons ' $n$ insig, skerp ons dit diep in, Heer, in ons gedagte en wys u grootheid vir ons nageslagte.

Dit wat ons kon bewerk het met ons hand, hou, Here, daardie werk van ons in stand. 


\section{Bybelse teks en die teks van die omdigting - 'n fragment uit Psalm 65}

\section{Bybelteks}

\section{Psalm 65:10-14}

(Die 1983-vertaling)

${ }^{10} U$ sorg vir die land en gee oorvloed,

$\mathrm{U}$ maak dit baie vrugbaar.

Die groot riviere is vol water,

U laat die koring welig staan.

Alles is $\mathrm{u}$ werk!

"U maak die ploegvore vol water en die kluite nat,

U laat hulle sag word van die reëns,

$U$ laat alles welig groei.

${ }^{12}$ U kroon die jaar met u goeie gawes.

Waar U ook gaan, is daar oorvloed!

${ }^{13}$ Daar is volop weiding in die woestyn:

die bulte juig,

${ }^{14}$ die velde wemel van die kleinvee,

die vlaktes staan vol koring:

hulle juig en hulle sing.

\section{Cloete-teks ${ }^{3}$}

\section{Psalm 65:5 \\ (die omdigting)}

U maak ons koringlande vrugbaar, die grond is week gereën, sag deur die kluite loop die ploegskaar, oorvloedig is U seen, Vol water is die groot riviere, die grasvelde staan ruig, daar's volop weiding vir die diere, die aarde sing en juig.

Wanneer die Cloete-teks van byvoorbeeld die vyfde strofe van Psalm 65 krities gelees word naas die vyf verse uit die Bybelteks van die 1983-vertaling, dan is dit duidelik dat 'n omdigting ook 'n suksesvolle verdigting tot gevolg het

3 Die teks van hierdie omdigting van Psalm 65 is reeds deur die Sentrale Tussenkerklike Afrikaanse Psalmkomitee goedgekeur. 
sonder dat die wesenlike van die Bybelse gegewens deur verskraalde segging gereduseer (hoef) te word.

'n Saamtrek van kerngedagtes uit die 1983-vertaling van Psalm 65:10-14 sou dalk soos volg kan lees:

1. God seën en maak vrugbaar

2. Daarom is daar oorvloed.

3. Op grond van hierdie seën sing en juig die ganse aarde.

In die Bybelteks van die 1983-vertaling is dit duidelik dat sekere woorde en frases herhalend voorkom. Ook woordeggo's kom verspreid in die teks voor.

1. God se seën word konkreet en sintuiglik waarneembaar deur die reën wat val. Die volkomenheid van die feit dat die reën 'n oorvloedige vrugbaarmakingsproses in werking stel, word taalmatig en betekenismatig herhaal - die riviere en ploegvore is "vol water" (v. 10 en 11), die vlaktes is "vol koring" (v.14), daar is "volop weiding" in die woestyn (v.13). Die aarde in sy omvattendheid deel in die seën: die landbougrond (vgl. die ploegvore wat vol water staan), die voorheen onbewerkte grond (vgl. die vlaktes wat vol koring staan) en selfs in die woestyn is daar volop weiding.

2. Ook word die graad van vrugbaarheid sigbaar in die woordkeuse om die oorvloed van die natuurgegewe te beskryf: die koring staan "welig" (v. 10), God laat "alles welig groei" (v. 11), daar is "oorvloed" (v. 12), daar is "volop weiding" in die woestyn (v. 13), die velde "wemel van kleinvee" (v. 14).

3. Op grond van hierdie seën, die feit dat God die jaar "kroon ... met ... goeie gawes", juig die skepping: die "bulte juig" (v. 13), die kleinvee en die vlaktes juig (v. 14).

\section{Cloete se weergawe van hierdie Skrifgedeelte}

Waar die Bybelteks egter die gegewens breed uitspin, is Cloete se omdigting 'n verdigting - maar sonder reduksie. Sy taalmatige interpretasie impliseer dat sonmmige herhalings uitgeskakel word, maar dat die neerslag van die kerngedagtes steeds behoue bly.

Die "oorvloed" van die Bybelteks vind by Cloete sy pendant in "oorvloedig is U seën". In die Bybelteks word vrugbaarheid vier maal in die woordkeuse benadruk: in die Cloete-teks word die idee van vrugbaarheid versober tot die vermelding dat die grasvelde "ruig" staan; dat daar "volop weiding" vir die diere is (v. 7). 
In die 1983-vertaling word die feit dat die skepping oor die oorvloed juig in gepersonifieerde vorm weergegee: die bulte juig, die velde en die kleinvee, die vlaktes vol koring juig en sing. Die omvattendheid van hierdie gejuig word by Cloete saamgetrek in die feit dat die "aarde" juig (v. 8).

Die konsentraat van die oorspronklike gegewe, die nukleus, het dus gebly en is nie lukraak in die omdigting verkort nie, maar die breër opset van die Bybelse teks is effektief en poëties in die Cloete-teks verdig. Die kerngegewens het konstant gebly en die resultaat van die omdigtingsproses is poëties, semanties en musikologies geslaagd.

Die doel met die omdigting van die Psalms is immers om uiteindelik 'n Skrifgetroue, maar ook 'n singbare teks in eenvoudige en verstaanbare Afrikaans daar te stel - vereistes waaraan hierdie fragment voldoen. 


\section{Mariana Venter}

\section{Psalmberymer}

Vir T.T. Cloete

Verwonderd leer jy luistersê

wat die oerteks in jou mond wil lê

sien jy die woord se dowwe syn

patroon vorm in jóú taal se grein.

Sekuur moet jy met jou vinger

oor die taalkontoere veeg

die lettergrepe tel en weeg

die denklyn las, die voeë pas,

die gidsspoor van die Dawidmerke

lees, weet waarom lelie, seder en palm

tuiskom in die skuilte van die psalm

die mossie deel is van Gods almagswerke.

En as jou nadink embrio word, jou woordwerk

vrylik asemhaal, die sin se samevloei

die saadkem van die Woord laat groei

tot vrug wat gloei met God se pneumamerk

sal jy sy voetval in die stiltes hoor.

Eers dan herskryf jou juigpsalm

die veelvlak van die Woordkristal

wat son maak in jou hand se palm. 
